Volume 4 No 1 September 2018 p-ISSN : 2460-8750 e-ISSN : 2615-1731

http://dx.doi.org/10.26858/talenta.v4i1.6529

\title{
TERAPI TAWA TERHADAP PENURUNAN TINGKAT STRES AKADEMIK PADA MAHASISWA STRATA 1
}

\author{
Sulfiani Juhamzah ${ }^{1}$, Widyastuti ${ }^{2,}$ Ahmad Ridfah $^{3}$ \\ ${ }^{1,2,3}$ Universitas Negeri Makassar \\ Email: sulfianijuhamzah@gmail.com ${ }^{1}$ widya_prasthya@yahoo.com ${ }^{2}$ \\ ahmad.ridfah@unm.ac.id ${ }^{3}$
}

C) 2018 -JPT Fakultas Psikologi Universitas Negeri Makassar. Ini adalah artikel dengan

akses terbuka dibawah licenci CC BY-NC-4.0 (https://creativecommons.org/licenses/by-nc/4.0/ ).

\begin{abstract}
Abstrack. Students are future leaders who are expected to have academic success as their primary goal. However, academic demands can lead to students experiencing academic stress.This study aims to determine the effect of laughter therapy on reducing stress levels in students. Research subjects amounted to $(N=10)$, which is a force of 2015 that fall into the category of high and medium stress. The researchers used the experimental design of the one group pretest-posttest design using a double pretest. The measuring tool used is the scale of academic stress. Reliability of the measuring scale by calculating the Cronbach Alpha coefficient with a value of 0.822 which signifies high reliability. This research uses Friedman Test data analysis technique that is processed with SPSS version 22. The results showed that the value of Asymp. Sig. 0.000 then $0.000<0,01$, so there is influence of laughter therapy which is very significant to decrease level of academic stress in student of Strata 1 Faculty of Psychology Universitas Negeri Makassar. This study provides a new alternative to the decrease of academic stress level in the students.
\end{abstract}

Keywords: Academic Stress, Laughter Therapy, Students

Abstrak. Mahasiswa merupakan calon pemimpin di masa depan yang diharapkan memiliki keberhasilan akademik sebagai tujuan utama mereka. Namun, tuntutan-tuntutan akademik dapat menyebabkan mahasiswa mengalami stres akademik. Penelitian ini bertujuan untuk mengetahui pengaruh terapi tawa terhadap penurunan tingkat stres pada mahasiswa. Subjek penelitian berjumlah $(N=10)$ yang merupakan angkatan 2015 yang masuk dalam kategori stres tinggi dan sedang. Peneliti menggunakan desain eksperimen the one group pretest-posttest design using a double pretest and posttest. Alat ukur yang digunakan adalah skala stres akademik. Reliabilitas skala ukur dengan menghitung koefisien Cronbach Alpha dengan nilai 0,822 yang menandakan reliabilitas tinggi. Penelitian ini menggunakan teknik analisis data Friedman Test yang diolah dengan SPSS version 22. Hasil penelitian menunjukkan bahwa nilai Asymp. Sig. sebesar 0,000 maka $0,000<0,01$, sehingga ada pengaruh terapi tawa yang sangat signifikan untuk menurunkan tingkat stres akademik pada mahasiswa Strata 1 Fakultas Psikologi Universitas Negeri Makassar. Penelitian ini memberikan alternatif baru terhadap penurunan tingkat stres akademik pada mahasiswa.

Kata Kunci: Stres akademik, Terapi Tawa, Mahasiswa. 
81 I Jurnal Psikologi Talenta Vol. 4 No.1

\section{PENDAHULUAN}

Keberhasilan pasti dibutuhkan oleh setiap individu, bukan hanya secara materi tetapi juga keberhasilan secara psikologis. Keberhasilan secara psikologis adalah merasakan kepuasan, kenyamanan, dan kebahagiaan. Namun, tuntutan-tuntutan akademik dapat menyebabkan mahasiswa mengalami stres akademik. Stres diartikan sebagai respon terhadap sebuah permintaan pada diri sendiri. Stres dapat terjadi dalam reaksi normal ketika otak mengalami suatu ancaman.

Lukaningsih dan Bandiyah (2011) mengemukakan bahwa stres merupakan suatu tuntunan untuk dapat beradaptasi dari individu ataupun reaksi individu terhadap tuntunan tersebut. Stres yang tidak mampu dikendalikan dan diatasi oleh individu akan memunculkan dampak negatif pada mahasiswa baik secara intelektual, emosional, fisiologis, dan perilaku. Dampak secara intelektual antara lain sulit berkonsentrasi, sulit mengingat pelajaran, dan sulit memahami pelajaran. Dampak secara emosional antara lain sulit memotivasi diri, munculnya perasaan cemas, sedih, kemarahan, dan frustasi. Dampak secara fisiologis antara lain gangguan kesehatan, daya tahan tubuh yang menurun terhadap penyakit, sering pusing, badan terasa lesu, lemah, dan insomnia. Dampak secara perilaku yang muncul antara
Terapi Tawa Terhadap Penurunan Tingkat Stres

lain menunda-nunda menyelesaikan tugas kuliah, malas kuliah, penyalagunaan obatobatan dan alkohol.

Agolla dan Ongori (2009) menemukan efek stres terhadap mahasiswa diantaranya $88 \%$ mahasiswa mengalami masalah pencernaan, $75 \%$ mengalami kecemasan di rumah atau di kampus, $32 \%$ makan, minum atau merokok berlebihan untuk mengurangi kecemasan, $77 \%$ merasakan ketegangan atau nyeri di leher atau bahu, sakit kepala, atau sesak nafas, $85 \%$ tidak dapat berhenti berpikir mengenai permasalahan mereka atau tidak dapat merasa tenang, $88 \%$ memiliki masalah dalam berkonsentrasi karena selalu mengkhawatirkan hal lain dan $61 \%$ mahasiswa memerlukan obat untuk menenangkan diri.

Damanik (2006) mengemukakan bahwa stres akademik merupakan segala sesuatu yang memiliki hubungan dengan reaksi fisiologis, perilaku, dan kognitif yang terjadi akibat adanya tuntutan yang berkaitan dengan masalah akademik. Hal tersebut dilakukan untuk memenuhi tuntutan yang akhirnya menimbulkan ketegangan ataupun tekanan yang tidak menyenangkan. Sehingga individu akan merasa terancam dengan tuntutan tersebut.

Govaerst dan Gregoire (2004) mengemukakan bahwa stres akademik dapat diartikan sebagai suatu keadaan individu ketika mengalami tekanan sebagai hasil persepsi dan penilaian individu tentang 
stresor akademik, yang berkaitan dengan ilmu pengetahuan dan pendidikan di perguruan tinggi.

Nurmaliyah (2014) mengemukakan bahwa stres akademik merupakan stres yang berhubungan dengan kegiatan belajar individu di sekolah maupun di perguruan tinggi, yang berupa ketegangan-ketegangan yang bersumber dari faktor akademik yang dialami individu sehingga mengakibatkan terjadinya distorsi pada pikiran individu yang mempengaruhi fisik, emosi, dan tingkah laku. Seorang individu akan mengalami stres akademik karena adanya tuntunan yang terkait dengan proses akademik atau karena perbedaan antara persepsi individu tentang pengetahuan yang luas.

Kholidah dan Alsa (2012) mengemukakan bahwa stres akademik yang dialami individu merupakan ketegangan atau beban yang dirasakan individu karena adanya tuntutan akademik, lingkungan sosial-budaya, penyesuaian diri dan sosial sebagai mahasiswa.

Gadzella dan Masten mengemukakan empat gejala stres yang paling umum muncul, yaitu gejala emosional seperti ketakutan, marah, rasa bersalah dan kesedihan. Gejala kognitif seperti kemampuan individu untuk mengidentifikasi dan menganalisis situasi stres, kemudian memikirkan bagaimana cara yang efektif untuk mengurangi tingkat stres.
Gejala perilaku seperti menangis, menyakiti orang lain, menyakiti diri sendiri, merokok, mudah marah kepada orang lain, percobaan bunuh diri dan memisahkan diri dari orang lain. Gejala fisiologis seperti berkeringat, gagap, gemetaran, gerakan cepat, kelelahan, penurunan atau penambahan berat badan, sakit kepala, nyeri pada tubuh, reaksi pada kulit, sakit perut, masalah pernapasan, dan sakit punggung.

Salah satu intervensi yang bisa diberikan sebagai bentuk terapi bagi mahasiswa yang mengalami stres akademik adalah Terapi Tawa.

Desinta dan Ramdhani (2013) menemukan bahwa terapi tawa dapat membantu individu untuk mencapai suatu kondisi rileks dan dapat mengurangi stres, tertawa selama 5-10 menit dapat merangsang pengeluaran endorphine dan seratonin yaitu sejenis morfin alami tubuh dan juga melatonin. Tertawa merupakan ekspresi jiwa atau emosional yang diperlihatkan melalui raut wajah dan bunyi- bunyian tertentu.

Hasil penelitian yang dikemukakan oleh Satish (2012) menyatakan bahwa penggunaan terapi tawa dapat membantu individu menyelesaikan masalah mereka, baik dalam bentuk gangguan fisik maupun gangguan mental. Penggunaan terapi tawa akan menghasilkan perasaan lega pada individu, hal ini disebabkan tawa secara alami menghasilkan pereda stres dan rasa 
83 I Jurnal Psikologi Talenta Vol. 4 No.1

sakit. Hasil penelitian ilmiah memperlihatkan bahwa kebahagiaan bukan hanya terletak dalam pikiran, tetapi terkandung dalam otot-otot dan hormon. Tindakan menggerakkan otot-otot wajah membentuk ekspresi yang berkaitan dengan kesukacitaan yang dapat menghasilkan efek positif yang berdampak pada sistem saraf.

Demir (2015) mengemukakan bahwa terapi tawa merupakan sebuah aplikasi yang berisi tentang latihan pernapasan dan gerakan fisik. Terapi tawa ini dimulai dengan latihan pernapasan yang tepat dan kemudian latihan tawa dengan cara melucu disertai gerakan.

Alvionita (2014) mengemukakan bahwa terapi tawa merupakan terapi relaksasi yang berguna untuk memperlancar peredaran darah sehingga dapat mencegah penyakit, memelihara kesehatan, dan menghilangkan stres. Dengan melakukan terapi tawa, individu akan dilatih untuk memunculkan respon relaksasi sehingga dapat mencapai keadaan tenang dan dapat memberikan pemijatan halus pada kelenjar-kelenjar dalam tubuh, menurunkan produksi kortisol dalam darah serta mengembalikan pengeluaran hormon secukupnya.

Firmanto (2006) menjelaskan prinsip-prinsip psikologi yang mendasari sesi tawa yaitu breathing (pernapasan), physical relaxation, mengembangkan kemampuan komunikasi, mencari social support, dan mental relaxation.
Terapi Tawa Terhadap Penurunan Tingkat Stres

\section{METODE}

Variabel bebas dalam penelitian ini adalah terapi tawa yaitu kegiatan terapi yang dilakukan dengan menggunakan humor dan tawa yang disertai dengan set gerakan. Variabel terikat dalam penelitian ini adalah stres akademik yaitu stres yang diungkap melalui gejala-gejala stres akademik seperti gejala emosional, kognitif, perilaku, dan fisiologis. Semakin tinggi skor yang diperoleh pada individu maka akan semakin tinggi stres akademik yang akan dialami.

Populasi dalam penelitian ini adalah 26 mahasiswa Fakultas Psikologi Universitas Negeri Makassar yang masuk dalam kategori mengalami stres akademik. Sampel dalam penelitian ini menggunakan teknik purposive sampling.

Metode pengumpulan data yang digunakan dalam penelitian ini adalah skala, yaitu skala stres akademik yang dibuat sendiri oleh peneliti berdasarkan empat gejala dari stres akademik (Gadzella \& Masten, 2005), yaitu gejala emosional, gejala kognitif, gejala perilaku dan gejala fisiologis. Validasi skala melalui analisis penilaian didasarkan pada rasio validitas isi Lawshe's CVR dari kelima professional judgement, diperoleh bahwa seluruh aitem dinyatakan esensial dengan angka CVR pada seluruh aitem bergerak pada angka 1 dari kelima professional judgment. Daya diskriminasi 
aitem skala stres akademik setelah dilakukan uji coba pada 201 orang subjek menunjukkan bahwa dari 29 aitem terdapat 5 aitem skala yang gugur, sehingga tersisa 24 aitem skala yang tersisa dengan rentang 0,272 sampai dengan 0,497. Berdasarkan hasil uji reliabilitas dari skala stres akademik, diperoleh hasil bahwa nilai alpha cronbach adalah 0,822. Sehingga, kriteria reliabilitas skala stres akademik dikategorikan ke dalam kriteria reliabilitas yang baik.

Rancangan penelitian yang digunakan adalah the one group pretest-posttest design using a double pretest and posttest melalui langkah-langkah terapi tawa sebagai berikut: a)Pelemasan bahu, leher, dan pinggang; b)Senam motivasi water melon; c)Tepuk tangan relaksasi tertawa; d)Tawa melambai asyik...asyik...asyik; e)Tawa berjabat tangan; f)Pernapasan pengatur kestabilan; g)Tawa pegas hahahahahaha; h)Relaksasi tubuh dan hening; i)Tawa berjalan, bernafas dan tersenyum; j)Tawa golden shake hand; k)Tawa lompat ceria; 1)Tawa cieee...cieee...cieee; m)Tawa cilukba; n)Tawa lingkaran besar dan kecil; o)Tawa dari hati ke hati; p)Pendinginan; dan q) Relaksasi tubuh dan hening

\section{HASIL DAN PEMBAHASAN}

Berdasarkan skor stres akademik pada kelompok eksperimen diperoleh hasil bahwa dari 10 orang subjek terdapat 9 orang subjek termasuk dalam kategori stres sedang dan 1 orang subjek termasuk kategori stres tinggi pada pretest 1 . Pada pretest 2 menunjukkan bahwa dari 10 orang subjek terdapat 9 orang subjek termasuk dalam kategori stres sedang dan 1 orang subjek termasuk dalam kategori stres tinggi.

Hasil posttest menunjukkan bahwa dari 10 orang subjek terdapat 9 orang subjek termasuk dalam kategori stres rendah dan 1 orang subjek termasuk dalam kategori stres sangat rendah pada postest 1. Pada posttest 2 menunjukkan bahwa dari 10 orang subjek terdapat 9 orang subjek dalam kategori stres rendah dan 1 orang dalam kategori sangat rendah.

Hasil pengujian hipotesis dalam penelitian dengan menggunakan uji Friedman Test menunjukkan nilai $\mathrm{p}=0,000$ $<0,05$. Nilai tersebut menunjukkan Ho ditolak dan $\mathrm{Ha}$ diterima, jadi dapat disimpulkan bahwa terdapat pengaruh terapi tawa terhadap penurunan tingkat stres akademik pada mahasiswa Strata 1 di Fakultas Psikologi Universitas Negeri Makassar.

Hasil uji perbandingan pengukuran pertama $(\mathrm{O} 1)$ dan pengukuran kedua $(\mathrm{O} 2)$ menunjukkan nilai $\mathrm{p}=0,171<0,05$. Nilai tersebut menunjukkan tidak terdapat perbedaan yang signifikan dari hasil 
85 I Jurnal Psikologi Talenta Vol. 4 No.1

pengukuran pertama $(\mathrm{O} 1)$ dan pengukuran kedua (O2) meskipun tanpa diberikan perlakuan.

Hasil uji perbandingan pengukuran pertama (O1) dan pengukuran ketiga (O3) nilai $\mathrm{P}=0,005<0,05$. Nilai tersebut menunjukkan terdapat perbedaan yang signifikan dari hasil pengukuran pertama (O1) dan pengukuran ketiga (O3) meskipun tanpa diberikan perlakuan.

Hasil uji perbandingan pengukuran pertama (O1) dan pengukuran keempat $(\mathrm{O} 4)$ menunjukkan nilai $\mathrm{p}=0,005$ $<\quad 0,05$. Nilai tersebut menunjukkan terdapat perbedaan yang signifikan dari hasil pengukuran pertama (O1) dan pengukuran keempat (O4) meskipun tanpa diberikan perlakuan.

Hasil uji perbandingan pengukuran kedua (O2) dan pengukuran ketiga (O3) menunjukkan nilai $\mathrm{p}=0,005<0,05$. Nilai tersebut menunjukkan terdapat perbedaan yang signifikan dari hasil pengukuran kedua (O2) dan pengukuran ketiga (O3) meskipun tanpa diberikan perlakuan.

Hasil uji perbandingan pengukuran kedua (O2) dan pengukuran keempat (O4) menunjukkan nilai $\mathrm{p}=0,005<0,05$. Nilai tersebut menunjukkan terdapat perbedaan yang signifikan dari hasil pengukuran kedua (O2) dan pengukuran keempat (O4) meskipun tanpa diberikan perlakuan.
Terapi Tawa Terhadap Penurunan Tingkat Stres

Hasil uji perbandingan pengukuran ketiga (O3) dan pengukuran keempat (O4) menunjukkan nilai $\mathrm{p}=0,066<0,05$. Nilai tersebut menunjukkan terdapat perbedaan yang signifikan dari hasil pengukuran ketiga (O3) dan pengukuran keempat meskipun tanpa diberikan perlakuan.

Subjek dalam penelitian ini mengaku bahwa stres akademik muncul ketika banyaknya tuntutan-tuntutan yang harus diselesaikan seperti banyaknya tugas yang menumpuk, deadline tugas, tidak mampu untuk membagi waktu, tugas yang susah untuk dikerjakan, jadwal kuliah yang padat dan kurangnya referensi buku. Ubaidillah (2014) mengemukakan bahwa stres akademik merupakan suatu respon yang timbul karena terlalu banyaknya tuntutan dan tugas yang harus diselesaikan oleh individu. Stres akademik yang dialami oleh individu merupakan hasil persepsi subjektif terhadap adanya ketidaksesuaian antara tuntutan lingkungan dengan sumber daya aktual yang dimiliki individu.

Subjek dalam penelitian ini juga memaparkan bahwa ketika stres akademik muncul, subjek mengaku bahwa akan mengalami gejala-gejala yang muncul pada dirinya seperti gejala emosional, gejala fisik, gejala perilaku dan kognitif. Nurmaliyah (2014) mengemukakan bahwa stres akademik merupakan stres yang berhubungan dengan kegiatan belajar 
individu di sekolah maupun di perguruan tinggi, yang berupa ketegangan-ketegangan yang bersumber dari faktor akademik yang dialami individu sehingga mengakibatkan terjadinya distorsi pada pikiran individu yang mempengaruhi fisik, emosi, dan tingkah laku. Individu akan mengalami stres akademik karena adanya tuntutan yang terkait dengan proses akademik atau karena disebabkan oleh perbedaan antara persepsi individu tentang pengetahuan yang luas.

Subjek dalam penelitian ini mengaku bahwa sumber stres yang dialami pada dirinya disebabkan karena frustrsi, adanya tekanan dan konflik yang terjadinya dalam dirinya. Stres terjadi ketika ada kesenjangan antara apa yang diinginkan dengan kenyataan yang ada. Gadzella dan Masten (2005) mengemukakan bahwa sumbersumber yang dapat menyebabkan munculnya stres yaitu, frustrasi yang merupakan adanya rintangan dan kegagalan untuk mencapai suatu tujuan, kurangnya sumber daya yang tersedia, merasa tersaing di dalam suatu lingkungan, adanya konflik dengan teman dekat, dan tidak memanfaatkan kesempatan yang memenuhi kualifikasi. Frustrasi muncul bila niat atau usaha individu terhalang oleh rintanganrintangan yang dapat menghambat kemajuan cita-cita yang berasal dari dalam diri sendiri maupun luar. Tekanan dapat terjadi karena adanya kompetensi, beban kerja yang berlebihan, tenggat waktu yang diberikan dan keinginan atau harapan yang tidak sesuai. Stres dapat timbul akibat adanya tekanan yang berhubungan dengan tanggung jawab yang besar yang harus ditanggung oleh individu itu sendiri. Konflik merupakan adanya suatu alternatif yang dibutuhkan dan tidak dibutuhkan untuk mencapai suatu tujuan dengan mempertimbangkan konsekuensi baik positif maupun negatif. Perubahan disebabkan karena adanya pengalaman yang tidak menyenangkan, sejumlah perubahan dalam satu waktu, serta gangguan dalam kehidupan dan gangguan dalam mencapai tujuan. Keinginan diri (selfimposed) merupakan keinginan untuk bersaing, keinginan untuk dicintai banyak orang, kekhawatiran mengenai banyak hal, dan mengalami kesulitan untuk mendapatkan solusi terhadap suatu masalah.

$$
\text { Folkman dan Lazarus }
$$
mengemukakan terdapat dua bentuk coping, yaitu yang berorientasi pada permasalahan (problem focused coping) dan yang berorientasi pada emosi (emotional focused coping). Terapi tawa merupakan strategi coping yang berorientasi pada emosi dimana teknik ini yang digunakan individu untuk mengatasi stres yang dialami. Emotion Focused Coping merupakan strategi penanganan stres dimana individu 
87 I Jurnal Psikologi Talenta Vol. 4 No.1

memberikan respon terhadap situasi stres dengan cara emosional, terutama dengan menggunakan penilaian defensif. Emotion Focused Coping merupakan strategi yang bersifat internal dan tujuan dari emotion focused coping yaitu untuk mengendalikan respon emosional dengan menggunakan pendekatan perilaku dan kognitif. Pendekatan perilaku dilakukan dengan cara mengalihkan perhatian individu dari masalah yang dihadapi. Sedangkan, pendekatan kognitif dilakukan dengan cara mengubah pikiran mengenai situasi yang menimbulkan stres seperti menolak kenyataan yang tidak menyenangkan. Individu biasanya menggunakan emotion focused coping ketika meyakini bahwa dirinya tidak mampu mengubah situasi atau kondisi yang menyebabkan stres (Folkman \& Lazarus, 1984).

Alvionita (2014) mengemukakan bahwa terapi tawa merupakan terapi relaksasi yang berguna untuk memperlancar peredaran darah sehingga dapat mencegah penyakit yang ada di dalam tubuh, memelihara kesehatan dan menghilangkan stres. Dengan melakukan terapi tawa, individu akan dilatih untuk memunculkan respon relaksasi sehingga dapat mencapai keadaan tenang dan dapat memberikan pemijatan halus pada kelenjar- kelenjar dalam tubuh, menurunkan produksi kortisol dalam darah serta mengembalikan pengeluaran hormon
Terapi Tawa Terhadap Penurunan Tingkat Stres

secukupnya. Terapi tawa dapat digunakan untuk membantu individu dalam mencapai kondisi rileks.

Desinta dan Ramadhani mengemukakan bahwa terapi tawa merupakan salah satu metode yang digunakan untuk mencapai suatu kondisi rileks. Terapi tawa juga dapat digunakan untuk menyelesaikan masalah baik dalam bentuk gangguan fisik maupun gangguan mental.

Demir (2015) menyebutkan bahwa terapi tawa merupakan sebuah aplikasi yang berisi tentang latihan pernapasan dan gerakan fisik. Terapi tawa ini dimulai dengan latihan pernapasan yang tepat dan kemudian latihan tawa dengan cara melucu dan disertai dengan gerakan. Stres yang dialami subjek yang disebabkan karena banyaknya tuntutan-tuntutan yang harus dipenuhi. Dengan tertawa, subjek akan mengeluarkanhormon endorphine yang berfungsi untuk mengurangi rasa sakit dan meningkatkan kekebalan tubuh. Kaur dan Walia (2008) mengemukakan bahwa tertawa dapat mengurangi peredaran dua hormon dalam tubuh yaitu efinerfin dan kortisol (hormon yang dikeluarkan ketika stres) yang akan dikeluarkan oleh hipotalamus. Jika kedua hormon tersebut dikeluarkan maka bisa menghalangi proses penyembuhan penyakit. 
Hasil ini sesuai dengan pernyataan dari Satish (2012) mengemukakan bahwa terapi tawa merupakan metode terapi dengan menggunakan humor dan tawa yang bertujuan untuk membantu individu dalam menyelesaikan masalah baik dalam bentuk gangguan fisik maupun gangguan mental. Penggunaan terapi tawa akan menghasilkan perasaan lega pada individu. Hal ini disebabkan tawa secara alami menghasilkan pereda stres dan rasa sakit.

Hasil penelitian ini sesuai dengan pernyataan Bennet \& Lengacher (2006) menyatakan bahwa terapi tawa merupakan suatu bentuk terapi yang di dalamnya terdapat reaksi fisiologis yang melibatkan otot wajah dan organ dalam tubuh. Selain fisik, terapi tawa juga memiliki pengaruh pada kesehatan mental. Tertawa terbukti dapat memperbaiki suasana hati dalam konteks sosial.

\section{KESIMPULAN}

Hasil penelitian menunjukkan ada pengaruh terapi tawa terhadap penurunan tingkat stres akademik pada mahasiswa Strata 1 di Fakultas Psikologi Universitas Negeri Makassar. Terdapat perbedaan tingkat stres akademik pada setiap pengukuran sebelum dan setelah pemberian terapi tawa pada mahasiswa.
Saran yang berkaitan dalam penelitian ini yaitu partisipan perlu menerapkan terapi tawa secara berkelanjutan agar dapat memberikan manfaat bagi kesehatan fisik dan mental. Diharapkan dengan penerapan secara kontinu dapat mengatasi stres akademik yang dialami. Saran untuk peneliti selanjutanya adalah penelitian dapat melibatkan dua kelompok partisipan sehingga makin menunjukkan besarnya kekuatan perlakuan yang diberikan dalam penelitian ini.

\section{DAFTAR RUJUKAN}

Agolla, J. E., \& Ongori, H. (2009).An assessment of academic stress among undergraduate students: The Case of University of Botswana. Educational Research, 4(2),063070 .

Alvionita, I. (2014). Pengaruh terapi tertawa terhadap depresi pada lansia di dusun jomegatan ngestiharjo kasihan bantul. (Naskah Publikasi). Yogyakarta: Universitas Muhammadiyah Yogyakarta.

Bennet, M. P., \& Lengacher, C. A. (2006). Humor and laughter may influence Health.Evidence-

BasedComplementary and Alternative Medicine, 3(1), 61-63.

Damanik, E. (2006). Pengaruh dukungan sosial teman sebaya terhadap stres akademik. Skripsi (Tidak diterbitkan). Makassar: Fakultas Psikologi Universitas Negeri Makassar.

Demir, M. (2015). Effects of laughter therapy on anxiety, stress, depression 
89 I Jurnal Psikologi Talenta Vol. 4 No.1

and quality of life in cancer patients. Journal of Cancer Science \& Therapy,7(9), 272-273.

Desinta, S., \& Ramdhani, N. (2013).Terapi tawa untuk menurunkan stres pada penderita hipertensi. Jurnal Psikologi, 40(1), 15-27. Firmanto, M. C. (2006). Pengaruh pelatihan tawa terhadap penurunan tingkat stres pegawai lembaga pemasyarakatan klas 1 surabaya di desa kebon agung kecamatan porong. Skripsi (Tidak diterbitkan). Surabaya: Fakultas Psikologi Universitas Airlangga.

Folkman, S., \& Lazarus, R. S. (1984). Stres, appraisal, and coping. New york: Springer Publishing Company.

Gadzella, B. M., \& Masten, W. G. (2005). An analysis of the categories in the student-life stress inventory. American Journal of Psychological Research, 1(1), 1-10.

Govaerst, S., \& Gregoire, J. (2004).Stressfull academic situations: Study on appraisal variables in adolescence. British Journal of Clinical Psychology. 54(4),261271

Kholidah, E. N., \& Alsa, A. (2012).Berpikir positif untuk menurunkan stres psikologis. Jurnal Psikologi, 39 (1), 67-75.

Lukaningsih, Z. L., \& Bandiyah, S. (2011). Psikologi kesehatan. Yogyakarta: Nuha Medika.

Nurmaliyah, F. (2014). Menurunkan stres akademik siswa dengan menggunakan teknik selfinstruction. Jurnal Pendidikan Humaniora, 2(3), 273-282.
Terapi Tawa Terhadap Penurunan Tingkat Stres

Satish, P. D. (2012). Laughter therapy. Journal of Pharmaceutical and Scientific,65(-), 1190-1204.

Ubaidillah, A. (2014). Hubungan antara kesejahteraan psikologi dan penyesuaian diri terhadap stres akademik pada mahasiswa baru fakultas psikologi universitas islam negeri maulana malik ibrahim malang tahun akademik 2013. Skripsi (Tidak diterbitkan). Malang: Universitas Negeri Maulana Malik Ibrahim 